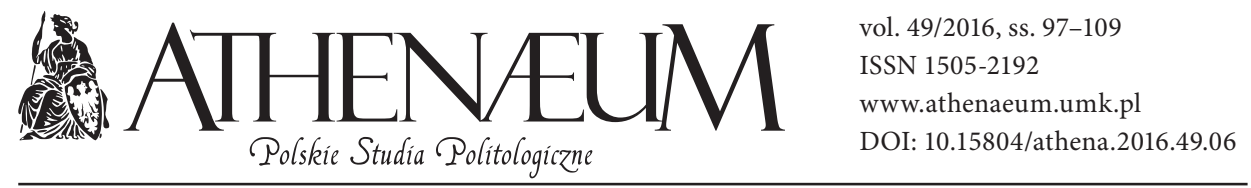

\title{
WYKORZYSTYWANIE SKANDALU DO TWORZENIA WIZERUNKU PRZEZ POLITYKÓW
}

\author{
THE USE OF SCANDAL \\ BY POLITICIANS TO CREATE THEIR IMAGE
}

Krystian Daniel*

\begin{abstract}
ABSTRAKT
Celem artykułu jest analiza wykorzystania skandalizacji jako specyficznego sposobu kształtowania wizerunku oraz przyciągania uwagi widowni. W tym kontekście autor zdefiniował pojęcie skandalizacji oraz określił przesłanki uzasadniające wykorzystanie takich mechanizmów w polityce. Analizując kariery wybranych polskich polityków, scharakteryzował wizerunek skandalisty oraz określił rolę takich osób na scenie politycznej. Ponadto wyróżnił i opisał cztery rodzaje skandalizacji: dyskredytacyjną, prowokacyjną, bulwersującą, celebrycką. Odnosząc się do tej typologii, sprecyzował kilka ogólnych wyznaczników wykorzystania mechanizmów skandalizacji do autopromocji i kształtowania wizerunku.
\end{abstract}

Słowa kluczowe: skandalizacja, wizerunek polityczny, marketing polityczny
The purpose of this article is to analyze the use of scandalization as a specific way of creating politicians' image and attracting the attention of the public. In this context, the author has defined the concept of scandalization and identified reasons justifying the use of such mechanisms in politics. By the analysis of the careers of selected Polish politicians, the author has characterized the image of a scandalous person and identified the role of such people in the political arena. Moreover, he has distinguished and described four types of scandalization: discrediting, provocative, shocking, and involving a celebrity. By referring to this typology, the author has identified a number of general considerations to the use of scandalization mechanisms for selfaggrandizement and image creation.

Keywords: scandalization, political image, political marketing

* Państwowa Wyższa Szkoła Zawodowa im. Jana Grodka w Sanoku, Instytut Społeczno-Artystyczny. 
Kreowanie pożądanego wizerunku ${ }^{1}$ jest jednym $\mathrm{z}$ kluczowych zadań wszystkich polityków, a szczególnie tych, którzy aspirują do stanowisk publicznych, obsadzanych nie tylko w drodze wyborów. Dla indywidualnych aktorów - czyli polityków, przywódców, kandydatów, tworzenie wizerunku jest najczęściej aktem tożsamym z budowaniem marki produktu, który później zamierza się sprzedać publiczności. W sferze politycznej odbiorcami są przede wszystkim wyborcy, media, inni aktorzy polityczni oraz konglomerat tych grup utożsamiany z opinią publiczną. Posiadanie dobrego wizerunku (tzn. pożądanego z punktu widzenia konkretnego polityka) świadczy o jego rozpoznawalności i reputacji, co w konsekwencji decyduje o karierze i obejmowanych stanowiskach. Dlatego współcześni politycy przykładają tak dużą wagę do kreowania własnego wizerunku, wykorzystując do tego różne działania z zakresu marketingu i public relations. Jednym z takich sposobów jest skandalizacja (definicję przedstawiono poniżej), na którą składa się wiele pomniejszych technik prowadzących do kształtowania pożądanego wizerunku. Działanie to jednak znajduje zastosowanie tylko w określonych przypadkach, a jego wykorzystanie wiąże się z pewnymi konsekwencjami.

Autor pragnie zaprezentować specyficzne ujęcie „polityki skandalu” (Castells, 2013) jako działania zmierzającego do uzyskania - jak to określił Thompson (2010) - „widoczności medialnej”, co znajduje odzwierciedlenie w postrzeganiu wizerunków danych podmiotów. Celem artykułu jest analiza wykorzystania skandalizacji jako specyficznego sposobu kształtowania wizerunku, a w szczególności określenie przesłanek uzasadniających stosowanie takich działań, ich

${ }^{1}$ Wizerunek (image) rozumiany jako „wyobrażenie, jakie jedna lub wiele publiczności ma o osobie, przedsiębiorstwie lub instytucji; nie jest to obraz rzeczywisty, dokładnie i szczegółowo nakreślony, ale raczej mozaika wielu szczegółów, podchwyconych przypadkowo, fragmentarycznie, o nieostrych różnicach" (Wójcik, 2005, s. 41). W związku z tym, że współcześnie obywatele znają polityków głównie z mediów, można mówić o tzw. wizerunku medialnym danego podmiotu. Taki image kształtowany jest za pośrednictwem środków masowego przekazu, co sprawia, że obywatele mają niewielkie możliwości sprawdzenia, czy polityk jest rzeczywiście taki, jakim go znają z mediów. W tym kontekście można mówić o tzw. efekcie Ottingera, czyli rozdźwięku między wizerunkiem wykreowanym a realnym. Biorąc to pod uwagę, można stwierdzić, że medialny image powinien korespondować z rzeczywistymi cechami danego polityka. Niewątpliwie ukształtowaniu dobrego wizerunku pomagają posiadane cechy, zarówno zewnętrzne (np. telegeniczność), jak i wewnętrzne, związane z osobowością (np. charyzma). Niektóre cechy można udoskonalić za pomocą szkoleń i praktyki, np. sposób wysławiania się, gestykulację, trzymanie emocji na wodzy. Biorąc to pod uwagę, Zaręba (2012) zaznacza, że kreacja wizerunku obejmuje kilka etapów: zbadanie obecnego wizerunku, odniesienie go do wizerunku idealnego, porównanie, tworzenie własnego wizerunku zgodnie $\mathrm{z}$ ustaloną koncepcją. Ponadto Podobas (2012) wskazuje, że kreacja wizerunku odbywa się na czterech płaszczyznach: merytorycznej, emocjonalnej, personalnej, komercyjnej. 
wyznaczników, rodzajów skandalizacji oraz cech charakteryzujących image skandalisty politycznego. Analizy dokonano na podstawie obserwacji karier wybranych polskich polityków: J. Palikota, J. Korwin-Mikkego, J. Kurskiego, S. Niesiołowskiego, A. Leppera (zm. 2011 r.).

\section{DEFINIOWANIE SKANDALU I SKANDALIZACJI}

Definicja skandalizacji wywodzi się od słowa skandal, które określane jest jako: „1. wydarzenie powodujące zgorszenie, oburzenie i zawstydzenie; 2 . atmosfera wywołana takim wydarzeniem" (Słownik języka polskiego). Wg Thompson’a (2010, s. 28) „pojęcie skandalu odnosi się do działań lub wydarzeń stanowiących naruszenie pewnych norm. O naruszeniu tych dowiadują się inni ludzie. Są one na tyle poważne, że wywołują reakcję opinii publicznej’' Skandale polityczne charakteryzują się przede wszystkim tym, że związane są z jednostkami i działaniami umiejscowionymi w sferze politycznej. Sednem takich skandali jest naruszenie obowiązujących norm i zasad należytego postępowania w polityce (wynikają one m.in.z przepisów prawa, procedur demokratycznych, zwyczajów). Warto jednak podkreślić, że współcześnie, pomimo funkcjonowania pewnych norm i zasad, o stopniu ich naruszenia w dużej mierze przesądzają rządzące podmioty oraz sympatyzujące z nimi media. Poprzez przyjęcie odpowiedniej narracji, dziennikarskich ram interpretacyjnych, można skutecznie zmienić wydźwięk i wyciszyć daną sprawę. Powodzenie takiego działania zależy m.in. od stosunków władz z mediami „głównego nurtu”.

W świetle powyższego termin skandalizacja (skandalizować) wykorzystuje się na określenie czynności i działań wywołujących skandal. Osoby, które go wzbudzają, nazywane są skandalistami lub skandalizatorami. W kontekście tego artykułu mechanizmy skandalizacji będą rozumiane jako celowe, świadome i kontrowersyjne działania podmiotów politycznych zmierzające do przyciągnięcia uwagi i wywarcia wpływu na odbiorców poprzez wywołanie szczególnego rodzaju atmosfery oburzenia, zgorszenia, zawstydzenia. Istotą tych działań jest przyciągnięcie uwagi - szczególnie mediów i innych aktorów politycznych poprzez zainspirowanie kontrowersyjnych działań, co odbywa się w sposób jawny, ostentacyjny, a nawet nachalny. Źródeł takiego postrzegania skandalizacji należy szukać w świecie show-biznesu, gdzie inicjowanie skandalu, najczęściej obyczajowego, zapewnia zainteresowanie mediów. Skandalizacja może znaleźć obszerne zastosowanie jako sposób autopromocji i kreowania wizerunku danego 
polityka. Kreacja image odbywa się poprzez szeroko rozumiane komunikowanie marketingowe, w ramach którego wyróżnia się trzy grupy narzędzi: 1. Reklamę polityczną, np. spoty telewizyjne i radiowe, ogłoszenia w prasie, billboardy; 2. Public relations, np. rzecznictwo prasowe, media relations, konferencje prasowe, wywiady, zarządzanie kryzysowe; 3. Marketing bezpośredni, np. pocztowa lub elektroniczna wysyłka materiałów promocyjnych, telemarketing, spotkania z wyborcami, wiece, canvassing (Dobek-Ostrowska, 2007). Mechanizmy skandalizacji umiejscowić można w ramach instrumentów i technik PR, szczególnie: reklamy nieodpłatnej (wywiady, konferencje prasowe, wystąpienia publiczne, wydarzenia specjalne), rzecznictwa prasowego (oświadczenia, artykuły do publikacji), media relations (nieformalne spotkania $\mathrm{z}$ dziennikarzami, wywiady). Te ostatnie działania mogą pomóc przekonać media do przedstawienia skandalu w odpowiednim świetle, pożądanym z punktu widzenia inspiratora. Ponadto skandalizację można traktować jako technikę kreowania pseudowydarzeń, tj. zaplanowanych wydarzeń konstruowanych na użytek mediów (Jabłoński, 2006). Skrajnym efektem skandalizacji może być ukształtowanie image skandalisty, co nieraz bywa zamierzonym celem niektórych polityków (o czym dalej). Ponadto skandalizację z powodzeniem wykorzystać można w przypadkach wymagających okresowego rozgłosu, np. w trakcie kampanii wyborczej.

Postrzeganie skandalizacji jako sposobu kreowania wizerunku ma źródło $\mathrm{w}$ kilku przesłankach. Po pierwsze, wiąże się to $\mathrm{z}$ rozwojem środków masowego przekazu i zdominowaniem przez media komunikacji na linii obywatele - politycy; po drugie, wynika ze specyfiki współczesnych mediów, które żyją sensacyjnymi, dramatycznymi, złymi, emocjonalnymi wiadomościami - takie informacje przyciągają uwagę odbiorców, wywołują silne bodźce (Gackowski, 2012), do czego skandale świetnie pasują; po trzecie, z charakteru podmiotów politycznych, które do bieżącej walki wykorzystują głównie argumenty emocjonalne, a nie racjonalne - przyczyną tego jest m.in. ujednolicenie programów politycznych; po czwarte, z nastawienia obywateli, którzy nie interesują się polityką, często jej nie rozumieją; i po piąte, $\mathrm{z}$ dopasowania narzędzi politycznej komunikacji do wymagań rynku medialnego (Jabłoński, 2006). W tym ostatnim kontekście warto zauważyć, że skandal, będąc sam w sobie naruszeniem pewnych norm, automatycznie przyciąga uwagę mediów. Ponadto dokonuje się to w zasadzie bez ponoszenia kosztów finansowych, które w przypadku takich działań, jak reklama telewizyjna albo prasowa, wiążą się ze sporymi wydatkami. Tym bardziej, że standardowe przekazy oparte na reklamie politycznej nie są już tak skuteczne, jak kiedyś. 
W związku z tym skandalizacja jawi się jako „tani” sposób przyciągania uwagi mediów i ogółu odbiorców. Jest to jednak dosyć ryzykowny tryb, którego powodzenie wiąże się z odpowiednim zaplanowaniem i przygotowaniem całej akcji autopromocyjnej, m.in. dobraniem instrumentów, sporządzeniem różnych scenariuszy zdarzeń. Istotą tych zabiegów jest takie sformułowanie przekazu, aby skandal został przedstawiony w mediach według przygotowanej przez inspiratora narracji. Jeśli tak się nie stanie, istnieje ryzyko, że akcja promocyjna zakończy się niepomyślnie. Ponadto, w zależności od konkretnego przypadku, skandalista może ponieść różne konsekwencje związane z jego publiczną krytyką, np. wizerunkowe (spadek wiarygodności), prawne (pozew o zniesławienie).

\section{TYPY SKANDALI I RODZAJE SKANDALIZACJI}

Thompson (2010) w sferze politycznej wyróżnia trzy podstawowe typy skandalu: 1. seksualne - charakteryzują się rywalizacją o władzę symboliczną i zasoby, istotne w perspektywie zdolności do sprawowania władzy; nie zawsze łączą się $z$ naruszeniem prawa; 2 . finansowe - mogą mieć konsekwencje symboliczne, polityczne, a często także prawne; 3. związane z nadużywaniem władzy - zwykle pociągają za sobą skutki symboliczne, polityczne oraz prawne. Autor, uzasadniając taki podział, wskazuje, że „normy i zasady rządzące relacjami o charakterze seksualnym, transakcjami finansowymi, a także dążeniem do władzy politycznej i jej sprawowaniem są szczególnie wrażliwe na skandal" (Thompson, 2010, s. 152). Z drugiej strony, relacje te budzą duże zainteresowanie, zarówno mediów, jak i innych grup odbiorców. Biorąc to pod uwagę oraz kierując się kryterium związanym z formą przyciągania uwagi, zaproponować można wyróżnienie kilku rodzajów skandalizacji: dyskredytacyjnej, prowokacyjnej, bulwersującej, celebryckiej. Kryterium to odwołuje się do czynników psychologicznych, które wywołują zainteresowanie ludzi, a z drugiej strony stanowią płaszczyzny wzbudzające różne bodźce emocjonalne. Każdy z wymienionych rodzajów skandalizacji bazuje na innych czynnikach, które przyciągają uwagę odbiorców z jednoczesnym rozbudzeniem pewnych emocji. Określenie tych czynników i bodźców wiąże się z analizą konkretnych przypadków. Należy jednak zauważyć, że wyróżnienie danego rodzaju to zabieg głównie teoretyczny, ponieważ w praktyce formy przyciągania uwagi wzajemnie się przenikają. Poniżej, w kontekście wykorzystania skandalu do kreowania wizerunku, dokonano charakterystyki każdego z zaproponowanych rodzajów skandalizacji: 
- Dyskredytacyjna - zmierza do wywołania skandalu poprzez atak na rywali, szarganie im reputacji, podkopywanie wiarygodności. Zwykle przybiera postać krytyki i oskarżenia przeciwnika o jakieś działanie, zachowanie, pomysł. Najczęściej są to oskarżenia o korupcję, wykorzystanie urzędu do celów prywatnych, nadużycie władzy, kłamstwo, niejasne powiązania, zachowania niegodne i/lub niepoprawne politycznie, ekscesy obyczajowe. Działania te mogą polegać nie tylko na imputacji czynów, ale także na ich amputacji. Inspirator skandalu bazuje tutaj na sformułowaniu zarzutu i podjęciu działań krytykujących ofiarę. Oczywiście prawdziwość zarzutu ma drugorzędne znaczenie. Sformułowanie oskarżenia sprawia, że inspirator staje się niejako źródłem informacji, tym, do którego inni zwrócą się o wyjaśnienia, przedstawienie dowodów na poparcie swoich twierdzeń. To spowoduje, że obok pomówionego stanie się on kluczową postacią sprawy obecną w przekazach medialnych. Zasadniczą korzyścią, jaką z tego tytułu osiąga inspirator, jest rozgłos, który później można zmierzyć m.in. za pomocą badań opinii publicznej (np. rozpoznawalności polityka). Jeżeli zarzut okaże się prawdziwy, inspirator ponadto zyskuje poważanie oraz zaufanie czy też wiarygodność w oczach odbiorców - w końcu jako pierwszy ujawnił szemrane interesy. Jeżeli zarzut okaże się nieprawdziwy, inspirator okrywa się niesławą, traci zaufanie i wiarygodność, ale zyskuje rozgłos i rozpoznawalność (zwykle także jego przeciwnik traci, pomimo tego, że zarzut był niesłuszny). Sprytny skandalista może uniknąć odpowiedzialności, tłumacząc się dobrem publicznym, chęcią wyjaśnienia krążących plotek, rozwiania pojawiających się wątpliwości. Może ponadto zostać nagrodzony przychylną postawą mediów.

- Prowokacyjna (zaczepna) - ten rodzaj skandalizacji opiera się na szeregu działań, które motywują (prowokują ${ }^{2}$ innych, co najmniej do ich skomentowania, wyrażenia opinii. Są to działania, obok których ciężko przejść obojętnie, w jakiś sposób trzeba na nie zareagować. W kontekście politycznym inspirator oczekuje głównie reakcji mediów i innych aktorów. Prowokacja może dokonać się za pomocą różnych czynności, m.in.: sugerowania jakichś nieprawidłowości lub ich wytykania, wraz z żądaniem wyjaśnień albo zachęcaniem mediów do podjęcia tematu (np. bezpośrednio w programie telewizyjnym); specyficznego zachowania

2 Prowokacja rozumiana jako „sztuczne wywoływanie zachowań ludzkich, zdarzeń, konfliktów, skłanianie ludzi do tego, do czego sami z siebie bynajmniej nie byliby skłonni” (Karwat, 2001, s. 425). 
(lekceważenia, ignorowania, ubliżania itd.); zwracania uwagi (wytykania błędów, zaniechań); podjudzania innych do działań szkodzących przeciwnikowi; organizacji różnych eventów i pseudowydarzeń (np. konferencji w hospicjum $\mathrm{z}$ jednoczesną sugestią, że władze łożą niewystarczające środki na opiekę nad chorymi i starszymi ludźmi). Jeżeli dane działanie zostanie wykonane w odpowiednim czasie (np. kampania wyborcza, okres strajków), to prawdopodobieństwo wywołania reakcji będzie znacznie większe. Jednak w skandalizacji prowokacyjnej nie chodzi bezpośrednio o wywołanie reakcji, raczej o utrzymywanie swojej roli inicjatora, podmiotu, który zwraca uwagę, zauważa daną kwestię, problem. To zapewnia inspiratorowi widoczność w sferze publicznej, kształtuje jego wizerunek jako inicjatora, a także swego rodzaju komentatora lub eksperta.

- Bulwersująca (kontrowersyjna) - odnosi się do działań, które przedstawiane są jako bulwersujące opinię publiczną lub jakąś jej część (np. wyborców prawicowych). W sferze politycznej najczęściej są to zachowania i wypowiedzi, które w zależności od grona odbiorców wywołują kontrowersje. Dla odbiorców lewicowych to np. informacje związane z przywilejami, jakie posiada Kościół katolicki w Polsce; dla prawicowych - kwestia dostępności aborcji; dla wszystkich razem: sprawy obyczajowe, marnotrawstwo pieniędzy publicznych (kupowanie reprezentacyjnych limuzyn, drogich mebli, wystawnych obiadów), wykorzystywanie urzędu i pozycji (zlecanie pracownikom transportu znajomych, przywiezienia obiadu, podjęcia czynności kontrolnych, zakładania podsłuchów itp.). O kontrowersyjności danych działań przesądza przede wszystkim sposób ich ukazania w mediach. Jedna redakcja może obrócić sprawę w żart i nadać jej humorystyczny wydźwięk, inna przedstawić ją jako poważny problem, aferę ${ }^{3}$. Charakter podejmowanych działań uzależniony jest od celów inspiratora. Tak więc w przypadku kreowania wizerunku z wykorzystaniem tego rodzaju skandalizacji inspirator będzie podejmował kontrowersyjne działania, które najczęściej przybierają postać wypowiedzi (zwykle radykalnych, nasiąkniętych wartościowaniem, budzących emocje) i działań (organizacji różnych eventów i pseudowydarzeń, np. spożywanie

3 Jeden z najsłynniejszych skandali, tzw. afera rozporkowa (USA, lata 90. XX w.), miał początkowo charakter obyczajowy - romans prezydenta. W momencie gdy B. Clinton publicznie wyparł się romansu ze stażystką, a później dowiedziono, że kłamał, sprawa nabrała charakteru poważnej afery prezydent kłamał. 
wódki lub palenie marihuany na konferencji; posługiwanie się różnymi akcesoriami i gadżetami typu: wibrator, pistolet, ucięta głowa świni).

- Celebrycka - bazuje na wykorzystaniu zachowań i działań ze świata show-biznesu. Aktorzy polityczni wykonują szereg działań, które w świecie „gwiazd” są od dawna uważane za standardowe i w przypadku celebrytów nie budzą kontrowersji, jednak w odniesieniu do polityków wywołują zdziwienie, oburzenie, szok, niesmak, kontrowersje, dezaprobatę. W przeciwieństwie do poprzednich rodzajów nie mają one wymiaru poważnej nieprawidłowości politycznej (m.in. są krótkotrwałe). Inaczej mówiąc, nie pociągają za sobą poważnych konsekwencji, np. w postaci postępowania prokuratorskiego. W sferze politycznej skandalizacja celebrycka może przybierać różne formy. Należą do nich: udział w sesjach fotograficznych, filmowych (np. spoty, w których kandydatka rozbiera się; zdjęcia polityka z nagim torsem), różnych programach rozrywkowych, w których tańczą, śpiewają, odpowiadają na pytania, także dotyczące życia prywatnego (programy talk show), eventach (np. pokazach mody, kontrowersyjnych rocznicach); publiczne ujawnianie różnych faktów ze swego życia prywatnego, tzw. dekonspiracja prywatności (Białek-Szwed, 2009); pokazywanie się z kontrowersyjnymi osobami, udzielanie im wsparcia (np. odwiedzanie pseudokibica $\mathrm{w}$ areszcie; poparcie dla artysty tworzącego bulwersującą rzeźbę papieża); wykazywanie się „kompromitującą” niewiedzą lub naiwnością; ostentacyjna odmowa wykonania powszechnie oczekiwanego działania, zgodnego z polityczną poprawnością. Poprawne wykorzystywanie tego rodzaju skandalizacji pozwala na kształtowanie wizerunku zgodnie z potrzebami danego podmiotu.

Wymienione formy skandalizacji zwykle wzajemnie się przenikają i w praktyce trudno wyróżnić jedną z nich. W tej materii sporo zależy od tego, jak potoczą się losy skandalu, czy wywoła on spektakl medialny czy też chwilowe oburzenie. Istotne znaczenie mają również działania samego inspiratora, szczególnie to, czy będzie on sterował losami skandalu, dążył do osiągnięcia jakichś celów, np. tych związanych z kształtowaniem wizerunku. Warto również podkreślić, że z powodu wewnętrznej dynamiki skandali czasami ich skutki dla skandalizowanych wykraczają poza ich zamiary, np. gdy po oskarżeniu ktoś popełni samobójstwo (Kepplinger, 2008).

Opierając się na wymienionych rodzajach skandalizacji, można spróbować określić pewne ogólne wyznaczniki wykorzystania takich działań do autopromocji i kształtowania wizerunku (należy jednak pamiętać, że mechanizmy 
skandalizacji bazują na wykorzystaniu różnych działań i technik, co sprawia, że wyróżnienie ich wyznaczników ma charakter teoretyczny). Po pierwsze, są one nastawione na rozgłos - skandalista chce zwrócić na siebie uwagę, chce, żeby o nim mówiono. W niektórych przypadkach znajduje tutaj zastosowanie zasada z show-biznesu: „nieważne co, ważne, żeby mówiono”. Po drugie, są one kontrowersyjne - co wynika z chęci przyciągnięcia uwagi. Po trzecie, dążą do sformułowania niestandardowego przekazu, który pozwoli na przebicie się w mediach. Po czwarte, odwołują się do emocji, a nie argumentacji merytorycznej. Po piąte, zmierzają do wywołania pewnych reakcji mediów i innych aktorów politycznych. Po szóste, pociągają za sobą konsekwencje dla inspiratora, m.in. specyficzne postrzeganie jego wizerunku np. jako skandalisty, hultaja.

W kontekście wymienionych czynników zauważyć można, że na skandalizację wpływa kultura polityczna w danym państwie (Thompson, 2005). O ile np. we Francji skandale związane z romansami polityków nie są wyolbrzymiane i traktowane jako poważne naruszenie, to w przypadku USA jest już odwrotnie. W Niemczech, tak jak i w Polsce, dużą wagę przywiązuje się do skandali związanych z korupcją i nadużyciami finansowymi. Ponadto w Polsce po $1989 \mathrm{r}$. nastąpiła implementacja wzorów zachowań politycznych z państw zachodnich, szczególnie USA. Procesy amerykanizacji i profesjonalizacji wpłynęły na przesunięcie granic dopuszczalnych zachowań politycznych. Niektóre działania, kontrowersyjne na początku lat 90., dzisiaj nie budzą już żadnych emocji, ludzie zaakceptowali je i przyzwyczaili się do nich. Ten proces powoduje, że politycy muszą sięgać po coraz to nowsze zabiegi, które pozwalają zwracać na siebie uwagę (Pietrzyk-Zieniewicz, 2004). Tym bardziej, że zmiany w mediach, np. związane z wpływem kultury popularnej (Piontek, Annusewicz, 2013), powodują, że domagają się one kontrowersji, tak jak nigdy przedtem. A i samo społeczeństwo zdaje się wykazywać spore zainteresowanie skandalami z udziałem polityków. W tym kontekście można pokusić się o stwierdzenie, że w Polsce dominują skandale o podłożu dyskredytacyjnym, a od początku XXI w. wzrasta zainteresowanie skandalizacją celebrycką.

\section{WIZERUNEK SKANDALISTY}

Zgodnie z powyższym wizerunek polityka skandalisty można postrzegać w co najmniej czterech wymiarach, które połączone mogą tworzyć całościową perspektywę do analizy cech składających się na model skandalisty. Pomocne w tym 
będą ustalenia m.in. D. Nimmo i R. Savage’a (Pietraś, 2000). Badacze wyróżnili 34 typy wizerunków wyodrębnionych na podstawie trzech kryteriów: roli politycznej, stylu politycznego, roli politycznej i stylu politycznego. Biorąc pod uwage to ostatnie kryterium, opisane przez nich wizerunki aroganta i manipulatora korespondują z obrazem skandalisty. Natomiast Jeziński (2004), klasyfikując wizerunki według kryterium cech politycznych, osobowościowych i stylu działania, wymienia dwa typy, które można powiązać z wizerunkiem skandalisty. Są to w. „ekscentryka” (np. J. Korwin-Mikke) i „błazna” (J. Urban). Modelowy wizerunek skandalisty można określić przez pryzmat jego cech charakteru, posiadanych umiejętności i pełnionych ról. Podstawowymi są:

a) cechy: oryginalność, wyrafinowanie, elastyczność, pomysłowość, aktywność, śmiałość, odwaga, otwartość, pewność siebie, zręczność, barwność, emocjonalność, poczucie wielkości, własnej wartości, siła charakteru, odporność na krytykę, nieprzewidywalność, skłonność do konfliktów, zachowań nieuczciwych i niestandardowych - wykraczających poza poprawność polityczną, brak zasad moralnych lub ich specyficzne rozumienie $^{4}$;

b) umiejętności: bycia w centrum uwagi, w świetle reflektorów, krytyki, posiadania własnego zdania innego od grupy, argumentacji, komunikacyjne (np. „wygadania”), bycia niejednoznacznym;

c) role: inicjatora, ekscentryka, spryciarza, błazna, aroganta, manipulatora, nonkonformisty.

Cechy te odnoszą się także do innych aspektów wizerunku, m.in. stylu politycznego, posiadanych poglądów i wartości.

W przypadku polskiej sceny politycznej, w której dominują ugrupowania partyjne, o wizerunku skandalisty przesądza rola odgrywana w ramach wewnętrznych struktur partii. Inaczej mówiąc, niektórzy politycy pełnią w swoich ugrupowaniach specyficzne role. Ich głównym celem jest przyciągnięcie uwagi, co zwykle dokonuje się poprzez działania określone wyżej jako skandalizujące szczególnie dyskredytację i prowokację przeciwników oraz bulwersowanie opinii publicznej. Celem skandalizacji może być w tym wypadku odwrócenie uwagi od jakiegoś realnego problemu poprzez wywołanie emocjonalnego oburzenia w stosunku do innych podmiotów lub nawet w stosunku do siebie. W powyż-

${ }^{4}$ Wielu autorów zwraca uwagę na etykę w kreowaniu wizerunku (Podobas, 2011; Drożdż, 2009). Jednak z punktu widzenia skuteczności politycznej etyka jest bardziej kwestią deklaracji niż praktyki działania. 
szym kontekście polityk skandalista jest wykorzystywany przez partyjne władze jako narzędzie do ich własnych celów, interpretowanych czasem przez pryzmat dobra ugrupowania.

W III RP taką rolę pełnili (w niektórych okresach): J. Kurski (np. sprawa dziadka z Wehrmachtu z 2005 r.), S. Niesiołowski (np. wypowiedzi o PiS po 2005 r.), J. Palikot (np. oskarżenie w 2008 r. L. Kaczyńskiego o problemy alkoholowe, konferencje prasowe z gadżetami, m.in. w 2007 r.). Pełnienie takiej roli partyjnej wiąże się jednak z pewnymi konsekwencjami, szczególnie przypinaniem danemu politykowi łatki skandalisty, prowokatora bądź, używając medialnych zwrotów: „niegrzecznego chłopca”, „harcownika” (Pawełczyk, 2012). Każdy z tych polityków nadal jest tak określany, ale np. w przypadku J. Palikota, po odejściu z PO i założeniu własnej partii, zauważyć można zmianę jego wizerunku.

Inną drogę do wizerunku skandalisty można zaobserwować w postawie i działaniach A. Leppera i J. Korwin-Mikkego. Obaj zasłynęli z kontrowersyjnych wypowiedzi i działań. A. Lepper przede wszystkim jako osoba dyskredytująca i prowokująca innych polityków oraz często działająca na granicy prawa lub poza nim, co jednak wynikało z charakteru działalności politycznej - oponenta, krytyka. W okresie po 2001 r., kiedy Samoobrona weszła do Sejmu, polityk nieco zmienił swój wizerunek, włączając w jego ramy elementy wynikające ze skandalizacji celebryckiej (np. opalenizna, pojawianie się w różnych programach rozrywkowych, organizacja psuedowydarzeń), aczkolwiek takie akcje, jak blokowanie sejmowej mównicy, nadal się zdarzały. J. Korwin-Mikke nie stronił od prowokacji i dyskredytacji, ale u podłoża jego wizerunku leżą przede wszystkim kontrowersyjne poglądy, które bulwersują opinię publiczną i wyróżniają polityka na tle innych. Do głośnych skandali z udziałem J. Korwin-Mikkego można zaliczyć m.in.: zjedzenie PIT-ów, jazdę na słoniu, telewizyjne sieg heil. Warto podkreślić, że obaj politycy przez prawie cały okres funkcjonowania na scenie politycznej pełnili rolę liderów własnych ugrupowań, jednak to A. Lepper odniósł zdecydowanie większe sukcesy. J. Korwin-Mikke dopiero w 2014 r. zdobył upragniony mandat.

Podsumowując, należy podkreślić, że kreacja wizerunku skandalisty dokonuje się poprzez własną, świadomą działalność i/lub przypisaną rolę w ramach struktury partyjnej. Oczywiście oba te sposoby nie wykluczają się i mogą być stosowane równocześnie. Pierwszy reprezentują kariery A. Leppera i J. Korwin-Mikkego, drugi - J. Kurskiego, J. Palikota, S. Niesiołowskiego. W przypadku J. Palikota - z perspektywy jego działalności politycznej od 2005 r. - można mówić o obu drogach do wizerunku skandalisty. 


\section{WNIOSKI}

Przeprowadzona analiza wskazuje, że skandalizację można postrzegać jako pewien specyficzny sposób kształtowania wizerunku politycznego oraz przyciągania uwagi widowni. Odgrywa to istotne znaczenie w okresach wymagających rozgłosu, np. kampaniach wyborczych. Ponadto należy podkreślić, że jest to sposób, który nie wymaga żadnych (lub niewielkich) nakładów finansowych, co jest jedną z głównych jego zalet. Wykorzystanie skandalizacji niesie za sobą jednak pewne konsekwencje. Są one związane przede wszystkim z charakterystycznym postrzeganiem wizerunku polityka, który ją stosuje. Politycy i media taką osobę często określają mianem: awanturnika, harcownika, hultaja, rozrabiaki. W skrajnym przypadku polityk jest postrzegany jako skandalista. Należy jednak podkreślić, że na taką reputację trzeba sobie zapracować działalnością długookresową. W świetle powyższego zaproponowano wyróżnienie i scharakteryzowano kilka rodzajów skandalizacji (dyskredytacyjną, prowokacyjną, bulwersującą, celebrycką), które bazują na różnych działaniach, głównie z zakresu PR. Odnosząc się do tej typologii, określono również kilka ogólnych wyznaczników wykorzystania mechanizmów skandalizacji do autopromocji i kształtowania wizerunku.

\section{Bibliografia:}

Białek-Szwed, O. (2009). Ekshibicjoniści polskiej sceny politycznej, W: M. Sokołowski (red.), Za kulisami spektaklu (s. 169-179). Toruń: Wydawnictwo Adam Marszałek. Castells, M. (2013). Władza komunikacji. Warszawa: Wydawnictwo PWN.

Dobek-Ostrowska, B. (2007). Komunikowanie polityczne i publiczne. Warszawa: PWN. Drożdż, M. (2009). „Być” to znaczy być w mediach - aksjologiczny wymiar medialnej „produkcji” wizerunków politycznych. W: M. Sokołowski (red.), Za kulisami spektaklu (s. 53-71). Toruń: Wydawnictwo Adam Marszałek.

Gackowski, T. (2011). Zamiast przedmowy. Manipulacja immanentną cechą mediów. W: T. Gackowski, J. Dziedzic (red.), Manipulacja w mediach. Media o manipulacji (s. 7-16). Warszawa: Wydawnictwo ASPRA-JR.

Jabłoński, J. (2006). Kreowanie informacji. Media relations. Warszawa: Wydawnictwo PWN.

Jeziński, M. (2004). Marketing polityczny a procesy akulturacyjne: przypadek III Rzeczypospolitej. Toruń: Wydawnictwo Naukowe Uniwersytetu Mikołaja Kopernika.

Karwat, M. (2001). O perfidii. Warszawa: Wydawnictwo Muza.

Kepplinger, H.M. (2008). Mechanizmy skandalizacji w mediach. Kraków: Wydawnictwo Uniwersytetu Jagiellońskiego.

Pawełczyk, P. (2012). Harcownik - nowy typ wizerunku politycznego. Środkowoeuropejskie Studia Polityczne, 2, 7-13. 
Pietraś, Z.J. (2000). Decydowanie polityczne. Warszawa-Kraków: Wydawnictwo PWN. Pietrzyk-Zieniewicz, E. (2004). Perswazja - język mediów. W: E. Pietrzyk-Zieniewicz (red.), Scena polityczna i media: miraże sukcesu, ryzyko autoprezentacji (s. 11-32). Warszawa: Wydawnictwo Elipsa.

Piontek, D., Annusewicz, O. (2013). Polityka popularna: celebrytyzacja polityki, politainment, tabloidyzacja. e-Politikon, 5, 6-28.

Podobas, I. (2011). Public relations jako narzędzie kreowania wizerunku partii politycznych. Warszawa: Wydawnictwo Difin.

Słownik Języka Polskiego. (2014). Skandalizacja. Pobrane z: www.sjp.pl.

Thompson, J.B. (2010). Skandal polityczny. Władza i jawność w epoce medialnej. Warszawa: Wydawnictwo PWN.

Thompson, J.B. (2005). The New Visibility. Theory, Culture \& Society, 22, 31-51.

Wójcik, K. (2005). Public Relations. Wiarygodny dialog z otoczeniem. Warszawa: Wydawnictwo Placet.

Zaręba, A.M. (2011). Wizerunek polityka w III RP: kreacja, instrumentarium, kompetencje komunikacyjne. Rzeszów: Wydawnictwo Uniwersytetu Rzeszowskiego. 